\title{
KONSEP PENGELOLAAN PAJAK YANG ADIL PERSPEKTIF IBNU KHALDUN
}

\author{
Jirhanuddin $^{1}$ Ahmad Dakhoir ${ }^{2}$ dan Sayri ${ }^{3}$
}

\begin{abstract}
ABSTRACK
This research is motivated by the thought of Ibn Khaldun regarding taxes. According to Ibn Khaldun if the tax is too low, can not lead a government function, if the tax is too high, fiscal pressure becomes too strong, so the profits traders and producers declined and there goes their incentive to work.The purpose of this study was to learn the concept of a fair tax management perspective by Ibn Khaldun in order to build a modern economy that is equitable and to find out how the tax relevance according to Ibn Khaldun with today's modern economy.

This research method used literature study (library research) with descriptive qualitative type of research. The data source consisted of Muqaddimah books as primary sources, work or theory that discussed of primary materials as secondary materials and the complement of primary and secondary materials as tertiary material. The approach in this study was a historical approach and philosophic. Data collection method used existing literature and data analysis used content analysis and the hermeneutic.

The study concluded that the concept of fair tax perspective of Ibn Khaldun is a tax that is withdrawn from the taxpayer in accordance with the ability of taxpayers to pay and the money tax collection should be used properly and fairly as possible, according to Ibn Khaldun when the tax burden lighter, people have an incentive to try to be more active. Therefore, the business world become more advanced, leading to greater satisfaction among the people, because of the low tax burden while tax revenue will also increase, judging from the overall resources of land tax, the thought of Ibn Khaldun regarding taxes is very relevant to be applied to the condition of modern economy of this time where the economic situation is less stable, the situation of society more complicated, the prices of expensive life needs make people's life difficult.
\end{abstract}

Key word: Concept, Tax Management, Fair.

\section{A. Pendahuluan}

\section{Latar Belakang}

Kontribusi kaum muslimin yang sangat besar terhadap kelangsungan dan perkembangan pemikiran ekonomi pada khususnya dan peradaban dunia pada umumnya, telah diabaikan oleh para ilmuan barat.Buku-buku teks ekonomi barat hampir tidak pernah menyebutkan peranan kaum muslimin ini. Menurut Chapra, meskipun sebagian kesalahan terletak di tangan umat islam karena tidak mengartikulasikan secara memadai kontribusi kaum muslimin. ${ }^{4}$

\footnotetext{
${ }^{1}$ Direktur Pascasarjana IAIN Palangka Raya, jirhan999@gmail.com

${ }^{2}$ Wakil Dekan I Fakultas Ekonomi dan Bisnis Islam, IAIN Palangka Raya, Ahmad.Dhakhoirciainpalangkaraya.ac.id

${ }^{3}$ IAIN Palangka Raya, sayri.rahman@yahoo.com

4 Adiwarman Karim, Sejarah Pemikiran EKonomi Islam, Jakarta: PT. RadjaGrafindo Persada, 2004, h. 8.
}

Jirhanuddin., Dakhoir,Ahmad., dan Sayri/ Jurnal Al-Qardh, Vol. 2, No. 2, Desember (2016) 
ISSN : 2354-6034

IAIN Palangka Raya

Ilmu ekonomi Islam berkembang secara bertahap sebagi suatu bidang ilmu interdisiplin yang menjadi bahan kajian para fukaha, mufassir, filosuf, sosiologi, dan politikus, sejumlah cendikiawan muslim terkemuka, seperti abu Yusuf (w.182 H), AlSyaibani (w. 189 H). Abu Ubaid (w. 224 H), Yahya bin Umar (w. 289 H), Al-Mawardi (w. 450 H), Al-Ghazali (w. 505 H), Ibnu Taimiyah (w. 728 H), Al-Syatibi (w. 790 H), Ibnu Khaldun (w.808 H), dan Al-Maqrizi (w. 845 H), telah memberikan kontribusi yang sangat besar terhadap kelangsungan dan perkembangan peradapan dunia, khususnya pemikiran ekonomi, melalui sebuah proses evolusi yang terjadi berabad-abad.

Latar belakang para cendikiawan muslim tersebut bukan merupakan ekonomi murni pada masa itu, klasifikasi disiplin ilmu pengetahuan belum dilakukan mereka mempunyai keahlian dalam berbagai bidang ilmu dan mungkin faktor ini yang menyebabkan mereka melakukan pendekatan interdisipliner antar ilmu ekonomi dan bidang ilmu yang meraka tekuni sebelumnya. Pendekatan ini mereka tidak memfokuskan perhatian hanya pada variabel-variabel ekonomi semata, para cendikiawan ini menganggap kesejahteraan umat manusia merupakan hasil akhir dari interaksi panjang sejumlah faktor ekonomi dan faktor-faktor lain, seperti moral, soasial, demografi, dan politik. ${ }^{5}$

Saat ini umat Islam Indonesia masih terkena beban ganda, yakni bayar zakat dan bayar pajak. Dualisme pemungutan ini pada gilirannya tentu akan menyulitkan pemilik harta atau pemilik penghasilan. Dengan diberlakukannya UU 38 Tahun 1999 dan UU Nomor 17 Tahun 2000, secara eksplisit diakui adanya perbedaan antara zakat dengan pajak.Pemberlakuan dua undang-undang tersebut memisahkan dengan tegas antara kewajiban menunaikan zakat bagi umat Islam dan kewajiban pajak bagi wajib pajak. Bagaimana sebaiknya menempatkan keduanya?. ${ }^{6}$

Pajak dan zakat dua instrument penghimpun dana masyarakat. Pajak didefinisikan sebagai instrument penghimpun dana yang digunakan oleh pemerintah untuk membiayai jalannya roda pemerintahan. Salah satunya adalah untuk membiayai sejumlah proyek infrastruktur dan berbagai fasilitas yang dibutuhkan masyarakat Indonesia.Pajak juga dapat digunakan untuk kepentingan sosial kemasyarakatan seperti untuk penanganan musibah bencana alam.

Sementara zakat didefinisikan sebagai instrument penghimpun dana yang telah ditetapkan Allah dalam Al-Quran bagi Muslim dengan ketentuan kebesaran tertentu. Berbeda dengan pajak, penggunaan dana zakat lebih terbatas. Zakat hanya bisa digunakan untuk kepentingan delapan golongan (asnaf) dalam Al-Quran. Salah satunya adalah untuk fakir miskin..dengan kata lain, zakat hanya diperuntukkan untuk kepentingan sosial. $^{7}$

Pajak yang dipungut oleh Negara kepada rakyatnya yang berasaskan kesewenangwenangan, kezhaliman, tidak maslahah yang dalam rentang sejarah peradaban yang dikenal dengan $M u k s$, upeti, dipungut berdasarkan kekuasaan yang zhalim adalah pajak yang non-syariah artinya yang tidak sejalan dengan prinsip-prinsip syariah.

\footnotetext{
${ }^{5}$ Umar Chapra, The Future Of Economics: An Islam Perspective, Jakarta: Shariah economics and banking Institute, 2001, h. 150.

${ }^{6}$ Noor Aflah, Arsitektur Zakat Indonesia, Jakarta: UI-Press, 2009, h. 73.

${ }^{7}$ Ibid, h. 74.
} 
ISSN : 2354-6034

IAIN Palangka Raya

Para fukaha mulai dari periode klasik, pertengahan sampai era modern telah menaruh perhatian serius terhadap perpajakan.Di antara beberapa pemikiran ilmuan klasik yang membahas mengenai hal tersebut ialah Ibnu Khaldun.

Ibnu Khaldun telah memiliki suatu visi yang jelas mengenai bagaimana faktorfaktor politik, ekonomi, moral, dan social beroperasi dalam suatu pola dinamik dan saling bergantung untuk mendorong pembangunan atau menjatuhkan suatu masyarakat. Dalam proses membahas persoalan ini, dia membuat sejumlah kontribusi penting ke dalam teori ekonomi. ${ }^{8}$

Ibnu Khaldun dengan tegas menekankan peran sektor swasta dan pemerintah dalam membangun ekonomi.Baginya, Negara juga merupakan faktor penting dalam produksi. Dengan pengeluarannya, Negara mampu mendorong produksi dan dengan pajak ia dapat mengurangi produksi.

Ibnu Khaldun telah menekankan prinsip perpajakannya dengan sangat jelas dalam muqaddimah. Ibnu Khaldun menyimpulkan bahwa "faktor paling penting untuk menciptakan atmosfer bisnis yang menguntungkan adalah meringankan sebanyak mungkin beban pajak pada pelaku bisnis, dengan tujuan menggalakan dunia usaha dengan cara memberikan jaminan keuntungan yang lebih besar." Hal ini ia jelaskan sebagai berikut:

"ketika beban pajak ringan, rakyat mempunyai insentif untuk berusaha lebih aktif. Karena itu, dunia usaha menjadi berkembang, yang menimbulkan kepuasan yang lebih besar di kalangan rakyat karena rendahnya beban pajak, sementara penerimaan dari pajak juga akan meningkat, dilihat dari keseluruhan sumber lahan pajak" lebih lanjut ia mengatakan bahwa: dengan berjalannya waktu, kebutuhan Negara akan meningkat dan laju perpajakan juga meningkat sehingga penerimaan juga demikian. Jika kenaikan ini gradual, orang akan terbiasa dengan suasana demikian, tetapi pada gilirannya akan ada dampak buruk pada insentif. Dunia usaha akan dirugikan dan merosot, demikian juga perolehan pajak. Dengan demikian, sebuah perekonomian yang makmur pada awal dinasti menerima perolehan pajak yang lebih tinggi dari laju pajak yang lebih rendah, sementara sebuah perekonomian yang mengalami depresi akan memperoleh penerimaan pajak yang lebih sedikit karena laju pajak yang lebih tinggi. Ia menjelaskan alasannya dengan mengatakan:

"ketahuilah bahwa bertindak tidak adil terhadap harta benda orang lain akan mengurangi kesediaan mereka untuk mencari kehidupan dan memperoleh kekayaaan dan jika ketidaksediaan untuk memperoleh kehidupan itu terus terjadi, mereka akan berhenti bekerja. makin besar tekanan, makin besar dampaknya pada usaha bekerja mereka dan jika rakyat tidak mau mencari penghidupan dan berhenti kerja, pasar akan mandeg dan kondisi rakyat akan memburuk" penerimaan dari pajak juga akan berkurang. Karena itu, ia mendukung keadilan dalam perpajakan. ${ }^{9}$

Berdasarkan beberapa masalah dan pemikiran yang telah diuraikan di atas, penulis merasa tertarik untuk menggali khazanah keilmuan klasik para pemikir ekonomi islam salah satunya Ibnu Khaldun dengan melakukan penelitian mengenai Bagaimanakonsep pengelolaan pajak yang adil perspektif Ibnu Khaldun.

\footnotetext{
${ }^{8}$ Umer Chapra, Masa Depan Ilmu ekonomi, Jakarta: Gema Insani Press, 2001, h. 137.

${ }^{9}$ Ibid, h. 140 .
} 
ISSN : 2354-6034

IAIN Palangka Raya

\section{B. Biografi Ibnu Khaldun}

Ibnu khaldun yang bernama lengkap Abdurrahman Abu Zaid Waliuddin Ibn khaldun lahir dari Tunisia pada awal Ramadhan $732 \mathrm{H}$ atau bertepatan dengan 27 Mei $1332 \mathrm{M}$. Berdasarkan silsilahnya, Ibn Khaldun masih mempunyai hubungan darah dengan Wail bin Hajar, salah seorang sahabat nabi yang terkemuka. Keluarga Ibn Khaldun yang berasal dari Hadramaut, Yaman, ini terkenal sebagai keluarga yang berpengetahuan luas dan berpangkat serta menduduki berbagai jabatan tinggi kenegaraan. ${ }^{10}$

1. Perjalanan Hidup Ibnu Khaldun

a. Fase pertama; Masa Pendidikan

Fase pertama ini dilalui Ibnu Khaldun di Tunis dalam jangka waktu 18 tahun, yaitu antara tahun 1332-1350 M. Seperti halnya tradisi kaum Muslim pada waktu itu, ayahnya adalah guru pertamanya yang telah mendidiknya secara tradisional, mengajarkan dasardasar agama Islam. Di samping ayahnya, Ibnu Khaldun juga mempelajari berbagai disiplin ilmu pengetahuan dari para gurunya di Tunis.

b. Fase kedua; Aktifitas Politik Praktis

Fase kedua dilalui Ibnu Khaldun dalam berbagai tempat seperti di Fez, Granada, Baugie, Biskara dan lain-lain, dalam jangka waktu 32 tahun antara 1350-1382 M. Karir pertama Ibnu Khaldun dalam bidang pemerintahan adalah sebagai Sahib al-Alamah (penyimpan tanda tangan), pada pemerintahan Abu Muhammad Ibn Tafrakhtn di Tunis dalam usia 20 tahun. (Mukti Ali, 1970:17)

Awal karir ini hanya dijalani Ibnu Khaldun selama kurang lebih 2 tahun, kemudian ia berkelana menuju Biskara karena pada tahun 1352 M Tunis diserang dan dikuasai oleh Amir Abu Za'id, penguasa Konstantin sekaligus cucu Sultan Abu Yahya al-Hafsh. Pada waktu Abu Inan menjadi raja Maroko, Ibnu Khaldun mencoba mendekatinya demi mempromosikan dirinya ke posisi yang lebih tinggi.Sultan Abu Inan bahkan beliau mengangkatnya sebagai sekretaris kesultanan di Fez, Maroko. Di kota inilah Ibnu Khaldun memulai karirnya dalam dunia politik praktis, yaitu pada tahun $1354 \mathrm{M}$.

c. Fase ketiga: Aktivitas Akademis dan Kehakiman

Masa ini merupakan fase terakhir dari tahapan perjalanan Ibnu Khaldun, fase ini dihabiskan di Mesir kurang lebih 20 tahun antara 1382-1406 M. Tiba di Kairo, Mesir pada 06 Januari 1983. Pada masa ini dinasti Mamluk sedang berkuasa. Kemajuan peradaban dan stabilitas politik saat itu menjadikan Ibnu Khaldun lebih tertarik dan karyanya al-Muqaddimah merupakan magnum opus atau kedatangan karyanya lebih dahulu daripada pengarangnya sehingga kedatangannya disambut gembira dikalarigan akademisi, disinilah tugas barunya sebagai seorang pengajar dilakukan Ibnu Khaldun. Ibnu Khaldun memberi kuliah di lembaga-lembaga pendidikan Mesir, seperti Universitas al-Azhar, Sekolah Tinggi Hukum Qamhiyah, Sekolah Tinggi Zhahiriyyah dan sekolah tinggi Sharghat Musyiyyah.

${ }^{10}$ Adiwarman Azwar Karim, sejarah Pemikiran Ekonomi Islam, Jakarta: PT. RadjaGrafindo Persada, 2008, h, 391.

Jirhanuddin., Dakhoir,Ahmad., dan Sayri/ Jurnal Al-Qardh, Vol. 2, No. 2, Desember (2016) 
ISSN : 2354-6034

IAIN Palangka Raya

2. Karya-karya Ibnu Khaldun

Selama masa hidupnya, Ibnu Khaldun telah membuat karya tulis besar yang dinamakan Al-I'bar, Nama lengkap dari kitab ini adalah Kitab al-I'bar wa Diwan alMubtada' wa al-Khabar fi al-A'yan wa al-A'rab wa al-A'jam wa al-Barbar wa man 'Asrahum min zawi as-Sultan al-Akbar. karya ini terdiri dari tiga buah buku yang terbagi ke dalam tujuh volume, diantaranya:

1). Muqaddimah (satu volume)

Merupakan pendahuluan dari kitab Al-I'bar, Buku tersebut memuat pembahasan tentang gejala sosial, termasuk didalammnya kegiatan ekonomi.

2). Al-I'bar (empat volume)

Buku yang memuat uraian tentang berita-berita mengenai bangsa Arab, generasi dan Negara-negara mereka sejak permulaan terciptanya ala mini hingga masanya Ibnu Khaldun. Di dalamnya, disebutkan pula secara ringkas bangsa-bangsa dan Negaranegara terkenal yang pernah hidup semasa dengan bangsa Arab, misalnya bangsa Nabata, Suryani, Persia, Bani Israil, Koptik, Yunani, Romawi, Turki dan bangsa Eropa. 3). At-Ta'rif bi Ibn Khaldun (dua volume)

Buku ini merupakan buku autobiografi dari Ibnu Khaldun, kemudian ia uraikan sebagian besar peristiwa yang ia alami semasa hidupnya. Selain mengungkapkan kepribadiannya, terdapat pengungkapan tokoh-tokoh yang mempunyai peranan penting dalam kehidupan politik dunia Islam saat itu, khususnya di daerah Maghribi.

Muqaddimah-muqaddimah dari Ibnu Khaldun, seperti yang kita lihat, telah dimuat di atas kertas "ditulis hitam di atas putih", sejak tahun 1382 tetapi Ibnu Khaldun kemudian telah banyak menambahkan dan mengubah hal-hal perlu dalam karyanya itu, sampai kirakira tahun 1402. ${ }^{11}$

1. Karya-karya lain

Selain karya yang telah disebutkan di atas, Ibnu Khaldun sebenarnya memiliki karya-karya lainnya seperti; Burdah al-Bushairi,tentang logika dan aritmatika dan beberapa resume ilmu fiqih. Sementara itu masih ada dua karya Ibnu Khaldun yang masih sempat dilestarikan yaitu sebuah ikhtisar yang ditulis Ibnu Khaldun dengan tangannya sendiri ini diberi judul Lubab al-Muhashal fl Ushul al-Din.Dan kitab Syifa al-Sailfi Tahdzib al-Masatt yang ditulis Ibnu Khaldun ketika berada di Fez, adalah karya pertama yang berbicara tentang teologi skolastik dan karya kedua membahas tentang mistisisme konvensional. $^{12}$

Ibnu khaldun mempunyai sejumlah besar murid, baik pada waktu ia mengajar di Tunisia di Universitas Al-Qasbah maupun pada waktu mengajar di Kairo (Al-Azhar dan tempat lain). Di antara murid-muridnya yang terpenting dan ternama antar lain:

1. Sejarawan ulung Taqiyuddin Ahmad Ibnu Ali Al-Maqrizi pengarang buku Al-Suluk li Ma'rifah Duwal Al-Muluk. Pada buku ini, Al-Maqrizi mengungkapkan bahwa guru kami Abu Zaid Abd Al-rahman Ibnu Khaldun datang dari negeri Maghrib dan mengajar di Al-Azhar serta mendapat sambutan baik dari masyarakat.

\footnotetext{
${ }^{11}$ Ismail Yakub, Terjemahan Muqaddimah Ibnu Khaldun, Jakarta: CV. Faizan, 1982, h. 9.

${ }^{12} \mathrm{Http} / \mathrm{H}$ :/KARYAKARYA\%20IBNU\%20KHALDUN\%20 \%20waroeng\%20eompoeg.htm (diunduh Kamis 8 September 2016 pukul 10:30 WIB)
}

Jirhanuddin., Dakhoir,Ahmad., dan Sayri/ Jurnal Al-Qardh, Vol. 2, No. 2, Desember (2016) 


\section{Konsep Pengelolaan Pajak yang Adil Perspektif Ibnu Khaldun}

Jauh sebelum Adam Smith (w.1790) yang terkenl dengan canons of taxation atau kaidah- kaidah perpajakannya (persamaan, kepastian, keyakinan pembayaran dan ekonomi dalam pengumpulan), Ibnu Khaldun telah menekankan prinsip perpajakannya dengan sangat jelas dalam Muqaddimah. Dia mengutip sebuah surat yang ditulis oleh Thohir bin AlHusaini, jenderalnya Khalifah Al-Makmun, yang sedang menasihati putranya Abdullah bin thohir, seorang gubernur dari provinsi Ar-Raqqah (Syria),"

oleh karena itu, distribusikan pajak-pajak di kalangan semua orang secara umum, jangan mengecualikan siapun karena kedudukannya atau kekayaannya dan jangan mengecualikan petugas-petugasmu atau pengikutmu. Janganlah kamu bebani siapapun dengan pajak yang berada di luar kemampuannya untuk membayar".

Dalam alinea ini, dia menekankan prinsip-prinsip persamaan dan netralitas. Sementara pada halaman yang lain, dia menekankan prinsip keyakinan dan produktivitas. Bahkan jauh sebelumnya, para fukaha telah menekankan prinsip ini terutama perlunya system pajak yang adil tidak menekan. ${ }^{13}$

Dampak pajak pada insentif dan produktifitas begitu jelas divisualisasikan oleh Ibnun Khaldun, sehingga tampaknya ia telah menguasai konsep perpajakan optimum. Dia telah mengantisipasi inti logika kurva Laffer, kurang lebih 600 tahun sebelum Profesor Arthur laffer mengemukannya, dalam dua babpembahasan dari Muqaddimah. Pada akhir bab pertama, ia menyimpulkan bahwa:

"faktor paling penting untuk menciptakan atmosfer bisnis yang menguntungkan adalah meringankan sebanyak mungkin beban pajak pada pelaku bisnis, dengan tujuan menggalakan dunia usaha dengan cara memberikan jaminan keuntungan yang lebih besar (setelah pajak)". Hal ini ia jelaskan sebagai berikut:

"ketika beban pajak ringan, rakyat mempunyai insentif untuk berusaha lebih aktif. Karen itu, dunia usaha menjadi berkembang, yang menimbulkan kepuasan yang lebih besar dikalangan rakyat karena rendahnya beban pajak, sementara penerimaan dari pajak juga akan meningkat, dilihat dari keseluruhan sumber lahan pajak". Lebih lanjut ia mengatakan

Bahwa dengan berjalannya waktu, kebutuhan Negara akan meningkat dan laju perpajakan juga meningkat sehingga penerimaan juga demikian. Jika kenaikan ini gradual, orang akan terbiasa dengan suasana demikian, tetapi pada gilirannya akan ada dampak buruk pada insentif. Dunia usaha akan dirugikan dan merosot, demikian juga perolehan pajak. Dengan demikian, sebuah perekonomian yang makmur pada awal dinasti menerima perolehan pajak yang lebih tinggi dari laju pajak yang lebih rendah, sementara sebuah perekonomian yang mengalami depresi akan memperoleh penerimaan pajak yang lebih sedikit karena laju pajak yang lebih tinggi. Ia menjelaskan alasannya dengan mengatakan:

" ketahuilah bahwa bertindak tidak adil terhadap harta benda orang lain akan mengurangi kesediaan mereka untuk mencari kehidupan dan memperoleh kekayaan dan jika ketidaksediaan untuk memperoleh kehidupan itu terus terjadi, mereka akan berhenti bekerja. makin besar tekanan, makin besar dampaknya pada usaha bekerja mereka dan jika rakyat tidak mau mencari penghidupan dan berhenti kerja, pasar akan mandeg dan kondisi rakyat

${ }^{13}$ Umer Chapra, Masa depan Ilmu ekonomi, Jakarta: Gema Insan Press, 20011, h. 140. 
ISSN : 2354-6034

IAIN Palangka Raya

akan memburuk" penerimaan dari pajak juga akan berkurang. Karena itu, ia mendukung keadilan dalam perpajakan. ${ }^{14}$

Ibnu khaldun juga menganalisis dampak belanja pemerintah pada ekonomi.Dalam hal ini, adalah pelopor dari Keynes. Dia mengatakan:

"suatu penigkatan dalam belanja pemerintah akan menyebabkan penurunan dalam penerimaan pajak. Alasannya Negara mewakili pasar terbesar bagi dunia dan sumber dari peradaban. Jika penguasa menimbun penerimaan pajak, atau hasil penerimaan ini hilang, dan ia tidak membelanjakannya untuk tujuan yang seharusnya , maka dana yang tersimpan pada kalangan istana dan pendukungnya akan berkurang. Demikian juga dan akan diberikan kepada para pegawainya dan anggota keluarga yang menjadi tanggungannya (dampak multiplier). Karen itu, belanja total mereka menjadi merosot. Mengingat bahwa mereka adalah bagian penting dari penduduk dan belanjanya bagian penting dari pasar, maka dunia usaha juga akan terganggu dan laju keuntungan usaha akan merosot, sehingga menimbulkan penurunan dalam penerimaan pajak. Kekayaan cenderung berputar pada segelintir orang dan penguasa, dari dia kepada mereka dan dari mereka kepada dia. Dengan demikian, jika penguasa menahannya untuk berbelanja, rakyat akan dijauhkan dari padanya. ${ }^{15}$

Pajak bervariasi menurut kekayaan penguasa dan penduduknya.Oleh karena itu jumlah pajak ditentukan oleh permintaan dan penawaran terhadap produk, yang pada gilirannya menentukan pendapatan penduduk dan kesiapannya untuk membayar. ${ }^{16}$

Jika pajak terlalu rendah, pemerintah tidak dapat menjalani fungsinya: "pemilik harta dan kekayaan yang berlimpah dalam peradaban tertentu memerlukan kekuatan protektif untuk membelanya',

Jika pajak terlalu tinggi, tekanan fiscal, menjadi terlalu kuat sehingga laba para pedagang dan produsen menurun dan hilanglah insentif mereka untuk bekerja: "jika pajak terlalu memberatkan dan laba yang yang diharapkan tidak terjadi insentif cultural akan hilang."

Oleh karena itu, Ibnu Khaldun membagi pendapatan nasional menjadi tiga kategori, yaitu gaji, laba, dan pajak, dan tiap-tiap kategori ini memiliki tingkat optimum, sekalipun demikian, tingkat optimum ini tidak dapat terjadi dalam jangka panjang, dan siklus aktifitas ekonomi harus terjadi. ${ }^{17}$

Uang yang dibelanjakan oleh pemerintah berasal dari penduduk melalui pajak. Pemerintah dapat meningkatkan pengeluarannya hanya jika pemerintah menaikkan pajaknya, tetapi tekanan fiskal yang terlalu tinggi akan melemahkan semangat kerja orang. Akibatnya, timbul siklus fiskal.apabila pemerintah memungut pajak yang kecil dan penduduk memiliki laba yang besar, maka mereka tersemangati untuk bekerja. Akan tetapi, kebutuhan pemerintah serta tekanan fiskal menjadi naik, sedangkan laba produsen dan pedagang turun, dan mereka kehilangan hasrat untuk berproduksi.Produksi menjadi turun, tetapi pemerintah tidak dapat menurunkan pengeluaran dan pajaknya.Akibatnya tekanan fiskal naik. Akhirnya, pemerintah menasionalisasi perusahaan-perusahaan karena produsen tidak memiliki insetif laba untuk menjalankannya. Kemudian, karena sumber daya finasialnya, pemerintah menjadi dominan di pasar dan mematikan produsen-produsen lainnya yang tidak dapat bersaing dengannya.laba turun, pendapatan pajak turun, dan

\footnotetext{
${ }^{14}$ Ibid,

${ }^{15}$ Ibid., h. 286.

${ }^{16}$ Boedi Abdullah, Peradaban Pemikiran Ekonomi Islam, Bandung: Pustaka Setia, 2010, h. 294.

${ }^{17}$ Ibid.,
} 
ISSN : 2354-6034

IAIN Palangka Raya

pemerintah menjadi lebih miskin dan harus menasionalisasi lebih banyak perusahaan. Orang-orang produktif meninggalkan negeri, dan peradaban runtuh:

"harus diketahui bahwa pada pernulaan dinasti, pajak menghasilkan pendapatan yang besar dari pembebanan yang kecil. Pada akhir dinasti, pajak menghasilkan pendapatan yang kecil dari pembebanan yang besar. Pada awalnya pendapatan pajak rendah .bila pembebanan pajak atas penduduk rendah, penduduk memiliki tenaga dan hasrat untuk bekerja . perusahaan cultural berkembang dan naik, karena pajak yang rendah menghasilkan kepuasaan. Apabila perusahaan cultural berkembang, jumlah iuran individual dan pembebanan pajak naik.Akibatnya pendapatan pajak naik.

Apabila dinasti tersebut tetap berkuasa (ia menjadi) maju setiap iuran dan beban individu naik secara besar-besaran, untuk mencapai pendapatan pajak yang lebih tinggi sehubungan dengan berangsur-angsurnya peningkatan pajak barang mewah dan begitu banyaknya kebutuhan-kebutuhan dinasti tersebut.

Pembebanan iuran meingkat melampaui batas kewajaran. Akibatnya minat penduduk dalam perusahaan-perusahaan kultural menjadi hilang, karena bila mereka membandingkan pengeluaran dan pajaknya dengan penghasilan dan pendapatan mereka, dan melihat kecilnya laba yang dihasilkan, mereka kehilangan harapan. Oleh karena itu, banyak diantara mereka mengundurkan diri dari semua aktifitas kultural. Hasilnya total pendapatan pajak turun, karena beban individual turun akhirnya, peradaban hancur, karena insentif aktifitas kultural hilang."

Aktifitas komersil yang dijalankan penguasa akan merugikan penduduk dan mengganggu pendapatan pajak persaingan antarmereka (penduduk) sudah menghabiskan sumber daya finansial mereka. Sekarang, jika penguasa yang memiliki begitu banyak uang dibandingkan mereka bersanding dengan mereka, jaranglah seorangpun dari mereka mampu mendapatkan hal-hal yang diinginkan (penduduk) dengan demikian menghabiskan modalnya dan harus berhenti berbisnis.

Jadi, bagi Ibnu Khaldun terdapat optimum fiskal, tetapi juga mekanisme yang tidak dapat dibalik sehingga memaksa pemerintah untuk membelanjakan lebih banyak dan memungut lebih banyak pajak, yang menimbulkan siklus produksi.Dengan demikian, Ibnu Khladun menguraikan sebuah teori dinamik berdasarkan hukum populasi dan hukum keuangan publik.Menurut hukum yang tidak bisa ditawar-tawar lagi, suatu negeri harus melalui siklus-siklus perkembangan ekonomi dan depresi. ${ }^{18}$

Secara ringkas, dari berbagai pandangan diatas, Ibnu Khaldun menemukan banyak pemikiran ekonomi yang mendasar beberapa abad sebelum kelahirannya "secara resmi" ia menemukan manfaat-manfaat dan perlunya pembagian kerja sebelum Smith dan prinsip nilai tenaga kerja sebelum Ricardo. Ia menguraikan teori populasi sebelum Malthus dan menandaskan peran Negara dalam perekonomian sebelum Keynes, masih banyak ekonom yang menemukan kembali mekanisme yang telah ditemukannya. Akan tetapi, lebih dari sekedar semua itu, Ibnu Khaldun menggunakan konsep-konsep untuk membangun suatu sistem yang dinamis dan koheren.

Dalam sistem ini mekanisme ekonomi tidak dapat tidak membawa aktifitas ekonomi kepada fluktuasi jangka panjang. Karena koherensi sistemnya, kritik yang dapat dilancarkan

${ }^{18}$ Ibid., h. 300.

Jirhanuddin., Dakhoir,Ahmad., dan Sayri/ Jurnal Al-Qardh, Vol. 2, No. 2, Desember (2016) 
ISSN : 2354-6034

IAIN Palangka Raya

terhadap kebanyakan konsep-konsep ekonomi yang menggunakan ide yang sama tidak dapat diterapkan disini. ${ }^{19}$

Ibnu khaldun mengemukan sebuah teorinya yang lain, yaitu, " model dinamika", seperti yang dikutiop oleh Mirza gamal. Ibnu khaldun dalam dalam teori dimaksud, mempunyai pandangan yang jelas bagaiman faktor-faktor dinamika sosial, moral, ekonomi, dan politik saling bebeda, tetapi saling berhubungan satu dengan lainnya bagi kemajuan dan kemunduran sebuah lingkungan masyarakat atau pemerintahan sebuah wilayah (Negara). Ibnu khaldun telah menyumbangkan teori produksi, teori nilai, teori pemasaran, dan teori siklus yang dipadu meenjadi teori ekonomi umum yang koheren dan disusun dalam kerangka sejarah. ${ }^{20}$

Kontribusi Ibnu Khaldun dalam pengembangan ilmu pengetahuan cukup signifikan, namun sayang, beliau lahir pada saat dunia Islam mulai mengalami kemunduran. Menurut Umar chapra seperti yang dikutip mirza Gamal kemunduran umat Islam dimulai sejak abad ke-12 yang ditandai dengan kemerosotan moralitas, hilangnya dinamika dalam Islam setelah munculnya dogmatisme dan kekuatan berfikir, kemunduran dalam aktivitas intelektual dan keilmuan, pemberontakan lokal dan pepecahan di antara umat, peperangan dan serangan dari pihak luar, terciptanya ketidak keseimbangan keuangan dan kehilangan rasa aman terhadap kehidupan dan kekayaan, dan faktor-faktor lainnya yang mencapai puncaknya pada abad ke16, yaitu pada masa dinasti Mamluk Ciscassiyah yang penuh korupsi, sehingga mempercepat proses kemunduran tersebut. ${ }^{21}$

1. Pajak dan faktor-faktor yang mempengaruhinya menurut Ibnu Khaldun

Setiap awal berdirinya sebuah Negara pemasukan akan sedikit tetapi membutuhkan pendapatan yang bnyak:

"Biasanya kondisi pajak pada masa awal daulah adalah sedikit yang dibagikan namun jumlah yang didapat banyak.Sedangkan pada masa akhir daulah jumlah yang harus dibagikan banyak, namun jumlah yang didapat sedikit". ${ }^{22}$

"Hal itu ialah karena daulah, apabila mengikuti ketentuan agama, maka dia tidak menuntut kecuali tanggungan-tanggungan syariat saja.Yaitu zakat-zakat, pajak bumi (kharaj) dan pajak kepala (jizyah). Dari semua itu sedikit saja yang harus dibagi karena kadar zakat dari harta adalah sedikit sebagaimana anda tahu. Demikian juga zakat biji-bijian dan binatang ternak, jizyah dan kharaj.Semua tanggungantanggungan syar'i itu adalah sudah ditentukan dan tidak bisa lebih dari ketentuan". ${ }^{23}$

Menurut Ibnu Khaldun pada awal berdirirnya sebuah kerajaan ataupun Negara membutuhkan pendapatan pajak yang tinggi untuk bisa cepat membangun sebuah Negara padahal pendapatan yang bisa diterima masih sedikit karena sedikitnya jumlah yang harus dikenakan pajak.

Negara yang mengikuti ketentuan agama tidak bisa menutut atau memaksa kecuali yang sudah ditentukan syariat seperti zakat. Akan tetapi kadar zakat dari harta sangat sedikit untuk dibagi sementara tanggungan syariat itu sudah mutlak ditentukan maka tidak boleh dikurangi ataupun dilebihkan dari ketentuannya.

\footnotetext{
${ }^{19}$ Ibid., h 301.

${ }^{20}$ Ibid.,

${ }^{21}$ Zainuddin Ali, Hukum Ekonomi syariah, Jakarta: Sinar Grafika, 2009, h. 44.

${ }^{22}$ Ibnu Khaldun, Muqaddimah (terjemahan), Jakarta Timur: Pustaka Al-kautsar, 2011, h. 493.

${ }^{23} \mathrm{Ibid}$.
} 

pajak:

Suatu pendapatan, gaji dan pembangunan yang dirasakan merupakan bagian dari

"Ketika pendapatan dan gaji yang dibebankan atas rakyat itu sedikit, maka mereka bersemangat dan senang bekerja. Hasilnya akan banyak pembangunan dan semakin bertambah hasil dari semangat itu akibat sedikitnya beban. Ketika pembangunan telah banyak maka bnyak juga gaji-gaji dan pendapatan-pendapatan itu.Akibatnya pajak juga menjadi banyak karena ia merupakan bagian dari pembangunan".

Pemerintah yang memberikan beban yang sedikit kepada rakyat untuk membangun. Maka, rakyat akan bersemangat untuk bekerja serta ikut membangun Negara. Dan semakin banyaknya pembangunan maka akan semakin banyak juga keuntungan yang dirasakan rakyat. Bila rakyat merasa hidup berkecukupan dan pendapatan banyak sedangkan beban sedikit maka rakyat akan taat membayar pajak dan akan menambah pendapat pajak Negara.

Ketika pemerintah menambahkan beban yang tinggi kepada rakyat akan mengurangi jumlah pajak:

"Namun kemudian penambahan itu sampai keluar dari batas wajar.Akibatnya, hilanglah semangat rakyat untuk membangun karena hilangnya harapan dari harta mereka, akibat sedikitnya manfaat dibandingkan beban tanggungannya dan antara buah dan manfaatnya. Maka banyak orang yang kemudian menggenggam tangan lalu berhenti membangun sama sekali. Maka berkuranglah jumlah pajak ketika itu akibat berkurangnya pendapatan darinya". ${ }^{24}$

Ketika rakyat di lakukan tidak adil dengan menambahkan beban yang sangat besar diluar batas kewajaran serta lebih besarnya tanggungan mereka dari pada manfaat yang mereka yang dapat, sehingga rakyat tidak bersemangat untuk membangun bersama dan akan mengurangi jumlah pajak dikarenakan rakyat sudah tidak bersemangat untuk berusaha dan bekerja maupun untuk membangun bersama karena merasa sangat dirugikan dengan tuntutan yang besar diluar batas kemampuan rakyat.

2. Hal yang merusak pendapatan pajak menurut Ibnu Khaldun

Pendapatan pajak akan berkurang dan rusak apabila disalah gunakan bukan untuk pembangunan negara:

"Ketika suatu kerajaan hasil pajaknya menjadi berkurang karena hal-hal sebagaimana telah kami kemukakan, yaitu kemewahan, banyaknya tradisi, belanja-belanja, penghasilan tidak tercukupi dengan berbagai kebutuhan dan belanjanya dan perlu adanya tambahan harta dan pajak, maka kadangkala ditetapkanlah berbagai macam pajak atas transaksi-transaksi jual beli dan pasar-pasar rakyat".

Pajak yang disalah gunakan bukan untuk pemabangunan Negara akan berdampak pada kehancuran Negara itu sendiri akibat dari bermewah-mewahan dan ditetapkannya lah berbagai macam pajak untuk menambah kebutuhan Negara dari pasar-pasar rakyat dan transaksi jual beli.

Negara harus mengawasi para petugas atau pengelola pajak agar tidak diselewengkan dan tersebut:

"Kadangkala dengan istilah-istilah pajak apabila sebelumnya telah ada.Kadangkala dengan membagi para pekerja dan para penarik dan mengawasi mereka karena

${ }^{24}$ Ibid, h. 494

Jirhanuddin., Dakhoir,Ahmad., dan Sayri/ Jurnal Al-Qardh, Vol. 2, No. 2, Desember (2016) 
kerajaan memandang bahwa mereka ini telah menghasilkan sesuatu yang bermanfaat dari harta pajak, yang tidak dapat ditampakkan hitungannya”.

Maka dari itu, sangatlah penting untuk pemerintah mengawasi lemabaga pajak, petugas pajak, dan setiap pegawai didalamnya. Karena mereka merupakan ujung tombak dalam menghimpun dana pajak dari masyarakat dan mengetahui berapa pendapatan pajak setiap tahunnya. Apabila mereka menyelewengkan dana pajak maka sudah pasti pemerintah dan rakyat akan dirugikan serta pembangunan Negara seperti sarana prasarana akan terhambat. rakyat:

Untuk menambah peningkatan pajak pemerintah harus ikut turun tangan bersama

"Kadangkala sultan melakukan perdagangan dan pertanian sendiri atas nama peningkatan pemasukan pajak.Karena kerajaan berpandangan bahwa para pedagang dan para petani menghasilkan berbagai keuntungan dan penghasilan selain mudahnya mereka memperoleh harta". 25

Untuk menambah pendapatan pajak Negara maka pemerintah harus ikut andil bersama rakyat dan seluruh elemen lainnya agar bisa mengatasi permasalahan yang sering tejadi. Karena Negara memandang sangatlah penting untuk ikut langsung dalam mengatasi perpajakan Negara agar cepatnya pembangunan yang akan dilakukan.

Pungutan besar yang dibebankan pemerintah kepada rakyat akan berdampak buruk bagi rakyat dan Negara:

"Kesulitan, kesempitan dan tidak adanya laba yang didapatkan rakyat tersebut dapat mencabut angan-angan mereka dari berusaha dalam bidang tersebut secara total dan menyebabkan rusaknya pajak. Sebab, kebanyakan pajak diambil dari para petani dan pedagang.Apa lagi setelah menerapkan pungutan-pungutan dan bertambahnya pajak karenanya. Apabila para petani telah surut dari pertaniannya dan para pedagang telah berhenti dari perdaganganannya maka hilanglah pajak secara keseluruhan. Atau setidaknya mengalami kekurangan yang signifikan. Apabila sultan membandingan antara apa yang di hasilkannya dari pajak dan antar keuntungan-keuntungan yang sedikit ini maka keuntungan-keuntungan itu jauh lebih sedikit. Kemudian hal itu meskipun bermanfaat, tetap saja hilang bagian besar dari pajak dalam penjualan dan pembelian yang dilakukannya.Sebab, tidak mungkin jika didalamnya terdapat pajak.Seandainya yang melakukan akad-akad itu adalah selain sultan, maka seluruh pekerjaannya terkena pajak". ${ }^{26}$

Pemerintah yang menerapkan pungutan-pungutan atau pajak yang dibebankan kepada rakyat terlalu tinggi, dan rakyat akan merasakan kesulitan, dan tidak diuntungkan. Maka, rakyat akan merasa tidak bersemangat untuk bekerja dan berusaha, bila rakyat malas untuk bekerja maka mereka pun tidak akan bisa membayar pajak dan pendapatan pajak pun akan hilang atau sangat berkurang secara signifikan dan ini akan menghambat pembangunan Negara.

Kota yang maju serta bangunan-bangunannya yang megah akan diikuti dengan mahalnya kebutuhan hidup:

"kami telah menyampaikan bahwa kota yang banyak pembangunannya menjadi khusus dengan kemahalan pasar-pasarnya dan harga-harga kebutuhannya, kemudian pajak-

${ }^{25}$ Ibid, h. 498

${ }^{26}$ Ibid

Jirhanuddin., Dakhoir,Ahmad., dan Sayri/ Jurnal Al-Qardh, Vol. 2, No. 2, Desember (2016) 
pajak semakin menambah mahalnya karena peradaban hanya terdapat ketika puncak kebesarannya, yaitu masa menerapkan pajak-pajak kerajaan karena banyaknya pengeluaran pada saat itu",27

Negara atau kota yang bangunannya megah dan mewah dimasa kemajuannya akan berdampak juga pada harga kebutuhan yang semakin tinggi dan mahal serta akan diikuti pajak yang tinggi untuk rakyat agar bisa menutupi pengeluaran-pengeluaran pada saat itu. harga barang:

Tingginya biaya barang yang dikenakan pajak akan mempengaruhi jual beli dan

" pajak-pajak berdampak pada berbagai jual beli yaitu menyebabkan harga barang mahal dan akibat rakyat dan para saudagar semuanya menghitung harga barang dagangan mereka dengan memasukan semua yang mereka belanjakan hingga upah diri mereka sendiri. Pajak masuk dalam nilai-nilai dan harga-harga barang yang diperjual-belikan. Akibatnya menjadi besar belanja-belanja warga peradaban dan beralih dari yang semula sedang menjadi berlebihan dan boros". ${ }^{28}$

Pajak sangat mempengaruhi dan berdampak pada transaksi jual beli yang menyebabkan barang mahal, serta adanya mencari keuntungan yang lebih oleh para pedagang akibatnya sangat berdampak pada kestabilan harga serta merubah sifat konsumtif masyarkat yang semula sedang berubah menjadi masyarakat yang boros.

\section{Relevansi pemikiran Ibnu Khaldun tentang pajak dengan kondisi ekonomi modern saat} ini

Ibnu Khaldun menegaskan, pada awal berdirinya kerajaan, perpajakan memperoleh pendapatan yang besar dari jumlah kecil dan pada akhirnya, kerajaan tersebut memperoleh pendapatan sedikit dari sumber yang banyak. Ibnu Khaldun merumuskan teorinya dengan mengatakan, pada mulanya Negara mengikuti ketentuan agama dan menetapkan beban sebagaimana ditentukan oleh syariah. Karena tidak banyak pajak dibebankan yang memiliki tingkat rendah. Tingkat pajak yang rendah memiliki dampak insentif terhadap kegiatan bisnis yang secara alamiah mendorong kegiatan perdagangan yang membuat meningkatnya sejumlah sumber.Pendapatan pajak meningkat bersamaan dengan kesejahteraan ekonomi, karena Negara meluas, penguasa umumnya gemar pada pembelanjaan yang tidak produktif.Karena itu, mereka menetapkan pajak baru dan bahkan meningkatkan jumlah sebelumnya.Ini mendorong pada dampak yang merugikan pada msyarakat. Mereka akhirnya berhenti pada kegiatan ekonomi dan Negara akan menghadapi kehancuran. ${ }^{29}$

Selain menganalisis dampak perpajakan terhadap pertumbuhan dan keruntuhan Negara, Ibnu Khaldun melihat dan mencela keterlibatan Negara dalam aktifitas perdagangan pada pihak penguasa, karena hal itu berbahaya bagi rakyatnya dan para pembayar pajak. Ia berpandangan, karena Negara berada pada posisi terdepan mengingat kekuasaan dan sumbernya, rakyat berada pada posisi yang tidak diuntungkan dalam kompetisi. Akibatnya, ini akan mendorong pada rusaknya bisnis swasta dan merosotnya pendapatan pajak bersamaan hilangnya keuntungan yang akan lepas dari para pedagang dan petani swasta. ${ }^{30}$

\footnotetext{
${ }^{27}$ Ibid, h. 666 .

${ }^{28}$ Ibid

${ }^{29}$ Sabahuddin Azmi, Menimbang Ekonomi Islam, Bandung: Nuansa, 2005. h. 216.

${ }^{30}$ Ibid, h. 217.
} 
pemikiran Ibnu Khaldun tentang ekonomi sesungguhnya sangat brilian yang mencakup berbagai permasalahan ekonomi, baik mikro maupun makro, apalagi pemikiran itu dikemukakannya pada abad 14 ketika Eropa masih terkebelakang. Ibnu Khaldun telah melakukan kajian empiris tentang ekonomi Islam, karena ia menjelaskan fenomena ekonomi yang terjadi di dalam masyarakat dan negara. Dari kajian makalah dapat disimpulkan bahwa secara historis, pemikiran Ibnu Khaldun tentang ekonomi jauh mendahului para sarjana Barat modern.Oleh karena itu, yang pantas disebut sebagai Bapak ekonomi adalah Ibnu Khaldun, bukan Adam Smith.

Pemikiran ekonomi Ibnu Khaldun sebagaimana yang telah diungkapkan telah banyak membahas berbagai masalah yang terkait pembahasan dalam ilmu ekonomi, seperti teori tentang nilai, pembagian kerja, sistem harga,hukum penawaran dan permintaan, konsumsi dan produksi, uang, pembentukan modal, pertumbuhan penduduk, makro ekonomi dari pajak dan pengeluaran publik, perdagangan, pertanian, industri dan perdagangan, kesejahteraan dan kemakmuran, dan sebagainya. Ia juga membahas berbagai tahapan yang dilewati masyarakat dalam perkembangan ekonominya. Pemikiran ekonomi Ibnu Khaldun telah memberi inspirasi para ekonom setelahnya, baik perkembangan ilmu pengetahuan di Timur dan Barat.Namun yang jauh lebih penting, pemikiran ekonominya relevan dan memberi prespektif baru dalam memotret persoalan ekonomi bangsa-bangsa di dunia juga termasuk di Indonesia.

Pemikiran ekonomi Ibnu Khaldun sangat relevan dengan keadaan perekonomian modern saat ini terutama masalah perpajakan. Seperti yang telah kita ketahui bersama banyak terjadi permasalahan didunia perpajakan di Indonesia mulai dari kurang taatnya wajib pajak, kurangnya pengetahuan masayarakat tentang pajak, tingginya pajak yang ditentukan pemerintah, serta penyelewengan dana pajak serta petugas pajak yang menimbun dana pajak tesebut. Ini merupakan permasalahan yang sangat serius untuk diatasi dan dibenahi sebaik mungkin agar dana pajak tersebut bisa digunakan dan manfaatkan sebaik mungkin untuk membangun Negara yang kuat dan maju.

Dari fakta di atas penulis dapat menyimpulkan bahwa pemikiran ekonomi Ibnu Khaldun sangat relevan dengan sistem ekonomi Islam dan keadaan perekonomian modern saat ini, sebab sesuai dengan prinsip-prinsip ekonomi islam, dan nilai dasar ekonomi Islam yaitu: Tauhid, Keadilan, kebebasan dan tanggung jawab.

Pemikiran Ibnu Khaldun tentang pajak, perdagangan internasional, usaha membangun peradaban dan politik sangat urgen untuk dipertimbangkan dalam konteks kekinian dalam rangka mewujudkan masyarakat dan negara yang sejahtera.Baldatun Thayyibatun wa Rabbun Ghafur.

\section{E. Penutup}

Berdasarkan bahasan hasil penelitian yang telah dilakukan oleh penulis, maka dapat disimpulkan:

Ibn Khaldun seorang tokoh dan pemikir muslim, nama lengkapnya Abd al-Rohman (Abu Zaid) bin Muhammad bin Abi Bakar bin Hasan. Ia dilahirkan di Trus pada tanggal 17 Mei 1332 M, dari keluarga Aristokrat yang berasal dari Hadramaut, dan wafat di Kairo pada 17 Maret $1406 \mathrm{M}$.

Menurut Ibnu Khaldun apabila beban pajak ringan maka masyarakat akan antusias membayar pajak dan sebaliknya apabila beban pajak tinggi maka masyarakat enggan 
ISSN : 2354-6034

IAIN Palangka Raya

membayar pajak dan semangat kerja mereka akan menurun. Selain itu, petugas pajak harus diawasi agar dana pajak tidak diselewengkan dan disalahgunakan karena akan menghambat pembangunan dan merugikan Negara.

Pemikiran Ibnu Khaldun tentang pajak sangat relevan jika diterapkan pada kondisi saat ini dimana keadaan perekonomian yang lagi tidak stabil dan kurangnya antusias masyarakat dalam membayar pajak dan banyaknya yang tidak taat dalam membayar pajak sehingga pemerintah mengeluarkan program Tax Amnesty untuk meringankan beban pajak yang ditanggung wajib pajak. Pemungutan dan penyaluran dana pajak harus efektif dan efesien Agar bisa mewujudkan masyarakat dan negara yang sejahtera. Baldatun Thayyibatun wa Rabbun Ghafur.

\section{F. Daftar Rujukan}

Abdullah,Boedi,Peradaban Pemikiran Ekonomi Islam, Bandung: Pustaka Setia, 2010.

Aflah, Noor,Arsitektur Zakat Indonesia, Jakarta: UI-Press, 2009.

Ali, Zainuddin,Hukum Ekonomi syariah, Jakarta: Sinar Grafika, 2009.

Azmi, Sabahuddin,Menimbang Ekonomi Islam, Bandung: Nuansa, 2005.

Chapra, Umar,The Future Of Economics: An Islam Perspective, Jakarta: Shariah economics and banking Institute, 2001.

Chapra, Umer,Masa depan Ilmu ekonomi, Jakarta: Gema Insan Press, 20011.

Chapra,Umer,Masa Depan Ilmu ekonomi, Jakarta: Gema Insani Press, 2001.

Http//H:/KARYAKARYA\%20IBNU\%20KHALDUN\%20 \%20waroeng\%20eompoeg.htm (diunduh Kamis 8 September 2016 pukul 10:30 WIB)

Karim, Adiwarman Azwar,sejarah Pemikiran Ekonomi Islam, Jakarta: PT. RadjaGrafindo Persada, 2008.

Karim, Adiwarman, Sejarah Pemikiran EKonomi Islam, Jakarta: PT. RadjaGrafindo Persada, 2004.

Khaldun, Ibnu, Muqaddimah (terjemahan), Jakarta Timur: Pustaka Al-kautsar, 2011.

Yakub, Ismail,Terjemahan Muqaddimah Ibnu Khaldun, Jakarta: CV. Faizan, 1982. 